\title{
CHARACTERISTICS OF POTENTIAL REPOSITORY WASTES
}

\author{
CONF-900406--11 \\ DE90 005455
}

\author{
Karl J. Notz \\ Oak Ridge National Laboratory*
}

for

First Annual International High-Level Radioactive

Waste Management Conference

(Invited paper for Session 2.4, System Data Development)

Las Vegas, April 1990

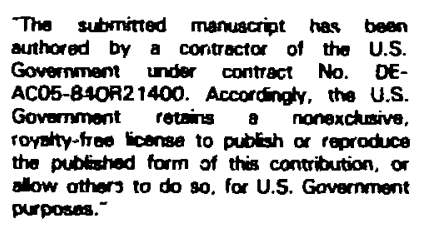

*Operated by Martin Marietta Energy Systems, Inc., under contract DE-AC05-84OR21400 with the U.S. Department of Energy

\section{MASTER}

IDI8TRIBUTIOH OF THIS DOCUMENT IS UMLIMITEL 


\author{
Karl J. Notz \\ Oak Ridge National Laboratory
}

\title{
Introduction
}

The Office of Civilian Radioactive Waste Management (OCRWM) is responsible for the spent fuels and other wastes that will, or may, evenually be disposed of in a geologic repository. The two major sources of these materials are commercial light-water

reactor (LWR) spent fuel and immobilized high-level waste (HLW). Other wastes that may require long-term isolation include non- $\mathrm{L} W \mathrm{~W}$ spent fuels and miscellaneous sources such as activated metals.

Detailed characterizations are required for all of thiese potential repository wastes. These characterizations include physical, chemical, and radiological properties. The latter must take into account decay as a function of time. In addition, the present inventories and projected quantities of the various wastes are needed. This information has been extracted from primary data sources, eviuated, and assembled in a Characteristics Data Base which provides data in four formats: hard copy standard reports, menu-driven personal computer (PC) data bases, program-level PC data bases, and mainframe computer files.

The Characteristics Data Base (CDB) is an integral part of the Systems Integration approach being used by OCRWM. In support of this effort, the CDB provides a standard set of self-consistent data to the various areas of responsibility within OCRWM, including systems integration and waste stream analysis, storage, transportation, and geologic disposal. The data will be used for design studies, evaluation of alternatives, and system optimization by OCRWM and supporting contractors.

The CDB was initiated, on a small scale, in 1985 and the first report was published in 1986, including one PC data base. 1 This report gave partial descriptions of BWR and PWR fuel assemblies, and the PC data base gave the radiological properties. The work 
was expanded in 1986 to cover the full scope of candidate wastes, and the first draft report was issued that year. Subsequently, two additional draft versions were issued and, finally, the formal report was issued in eight volumes and two printings ${ }^{2}$, including five PC data bases.

\section{Qverview of CDB}

The Characteristics Data Base is organized on the basis of four major waste stream categories: LWR Spent Fuel, Immobilized High-Level Waste, Non-LWR Spent Fuels, and Miscellaneous wastes. These can be further broken down into eight waste streams (Fig. 1). For HLW, the generator site identities are retained, and the basic units are individual canisters of immobilized HLW. For LWR spent fuel, the basic units are the individual assemblies, and the distinctions between BWRs and PWRs warrant separation on this basis; the generating reactors are also identified. For non-LWR spent fuels and miscellaneous wastes, the as-stored characteristics are the present basis, but as predisposal treatment and packaging concepts are developed, these will be incorporated.

The above four major categories, plus a summary, comprise the five major sections of the hard copy report ${ }^{2}$, which was recently issued as an 8-volume set. Six of these volumes consist of 16 appendices that provide supporting information to the other two volumes. There are approximately 50,000 data entries in these volumes, about $1 \%$ of all the data in the PC data bases.

Five of the appendices are Users' Guides to as many menu-driven PC data bases. No programming skills are required to use these, which are described in Table 1. Two more such data bases are under development, one with data on LWR fuel pin characteristics and one for LWR assembly serial numbers. These data bases are designed for use on an IBM-PC or PC-compatible hardware. A total of 20 megabytes of disk storage is required for all of them; this represents about 5 million data entries, about $80 \%$ of them radiological 
0
$\vdots$
0
0
0
$\vdots$
0
$\vdots$
0
0
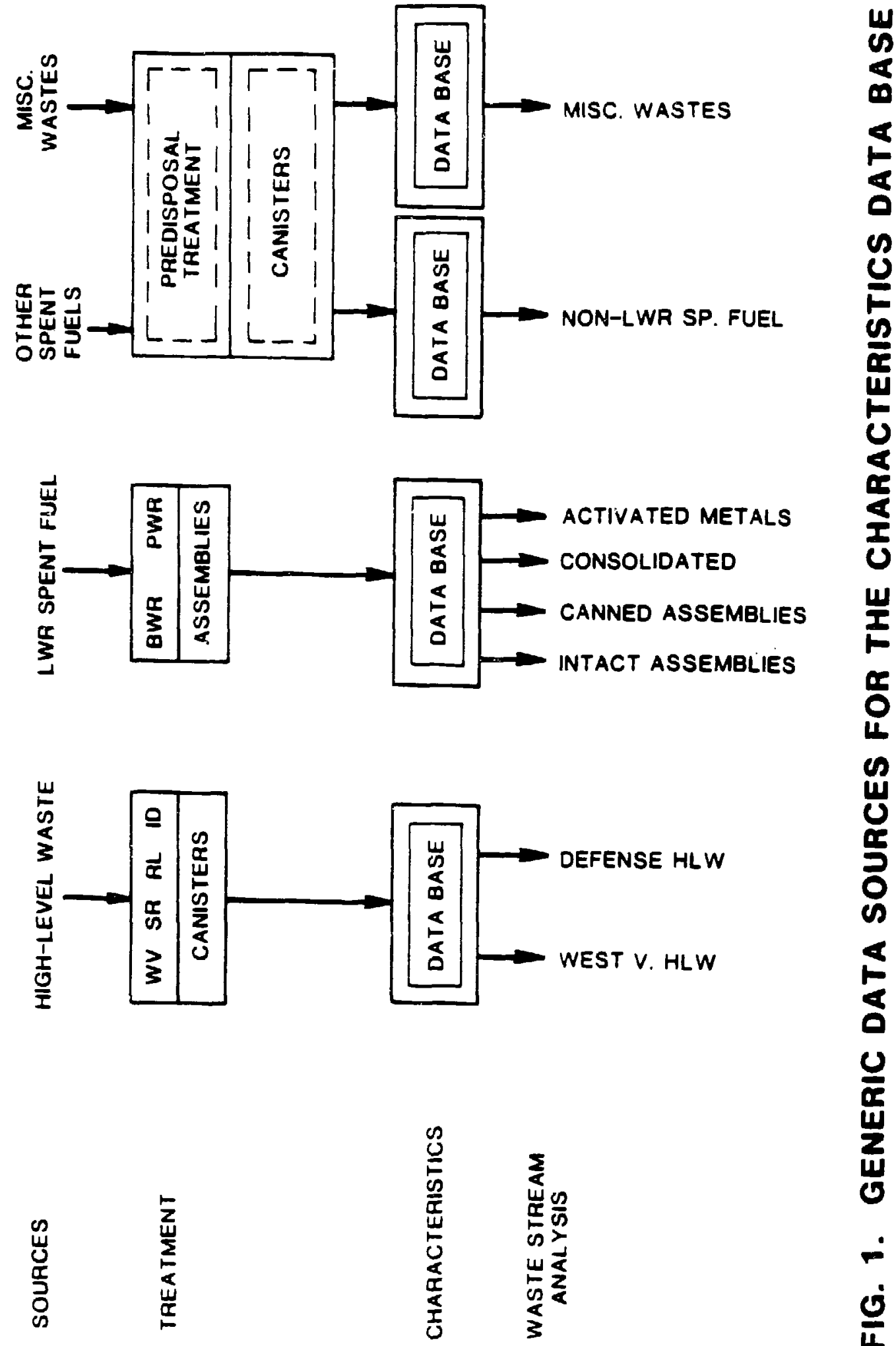


\section{Table 1. Menu-driven PC Data Bases Available fin ing Characteriscics Data Base}

LWR Radiological Data Base - Contains radionuclide compositions, heat generation rates, curies, photon spectra, and ocher information as a function of spent fuel type, bumup, and decay time.

LWR Assemblies Data Base - Contains detailed physical descriptions of fuel assemblies and radiological properies of spent fuel disassembly (SFD) hardware.

High-Level Waste Data Base - Contains physical, chemical, and radiological descriptions of high-level waste, both as the interim form and the immobilized form in canisters.

LWR NFA Hardware Data Base - Contains physical and radiological descriptions of nonfuel assembly hardware; i.e. nonfuel-bearing hardware other than SFD hardware.

LWR Quantities Data Base - Contains data on discharged fuel, as historical inventories and as projected quantities, based on EIA data supplied to them by the utilities.

\section{DISCLAIMER}

This report was prepared as an account of work sponsored by an agency of the United States Government. Neither the United States Government nor any agency thereof, nor any of their employees, makes any warranty, express or implied, or assumes any legal liability or responsibility for the accuracy, completeness, or usefulness of any information, apparatus, product, or process disclosed, or represents that its use would not infringe privately owned rights. Reference herein to any specific commercial product, process, or service by trade name, trademark, manufacturer, or otherwise does not necessarily constitute or imply its endorsement, recommenriation. or favoring by the United States Government or any agency thereof. The views 
data and the balance descriptive data and quantities of materials. They are available through the Oak Ridge National Laboratory; ordering information is given in the report ${ }^{2}$ on page $v$.

The above data bases, as well as many of the internal working files, are written in dBASE III FLUS. This permits tabulation of special reports and interactive output. Mainframe files are used to generate some of the above files and some of the hard copy reports. Their use involves SAS and FORTRAN. A generalized flow chart for data processing is shown in Fig. 2.

The radiological characteristics are calculated using ORIGEN $2^{3}$, and include:

- quantities of each nuclide (grams or gram atoms);

- radioactivity, total and by nuclide (curies);

- thermal power, total and by nuclide (watts);

- photon energy spectra, by energy group (18 groups);

- neutrons from spontaneous fission (per second);

- neutrons from (alpha, $n$ ) reactions (per second); and

- quantity of each element (grams or gram atoms).

The above characteristics are decayed over time, for 24 (or more) time periods from 1-yr to 1 -million years. An interpolation function is provided for those users who may need data at intermediate times. For LWR spent fuel, the integral heats (thermal power, integrated over time) are also available, between any two times out of a set of 38 times, also spanning 1 - to 1 -million years.

\section{LWR Spent Fuel}

Data on LWR spent fuel constitutes the largest portion of the Characteristics Data Base, because of the large quantities of material involved and because of the complexity of the data. The data base must deal with 78 (at present) different assembly types or models, over a wide range of fuel burnups ( 5 to $60 \mathrm{GWd} / \mathrm{MTU}$ ), both actually discharged and projected for future discharge, and the radiological properties over time not only for the fuel itself, but also for the associated hardware. In addition, although most of this fuel is 


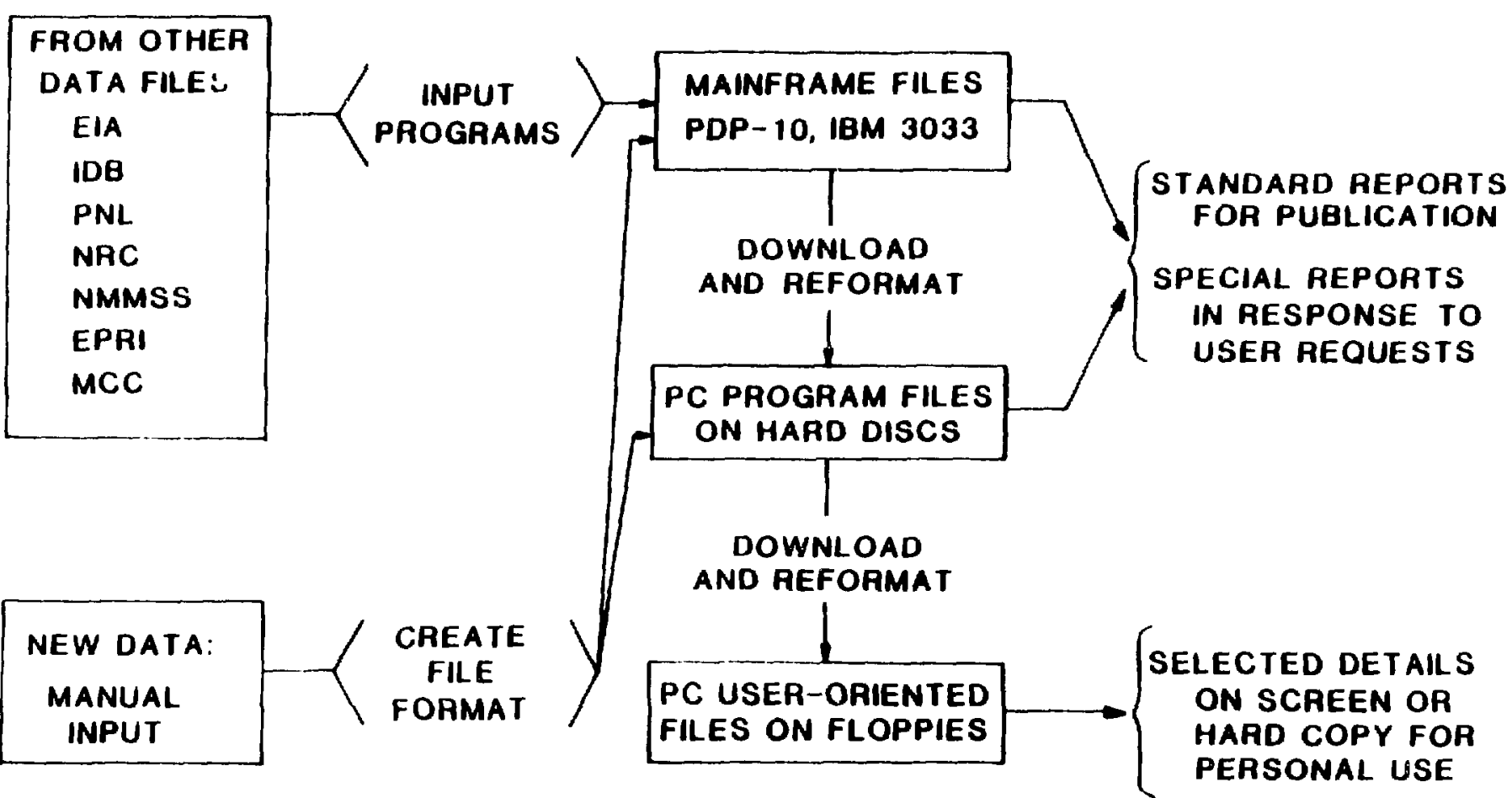

FIG. 2. DATA FLOW IN THE CHARACTERISTICS DATA BASE 
presently in the form of uncanned intact assemblies, some is canned and more of this can be expected (for defective fuel), and future practices may result in spent fuel disassembly and consolidation, which will give rise to activated metals from the hardware components. Figure 3 shows schematically the flow of input and output data for LWR spent fuel. More detailed information on this part of the data base is provided in Chapter 2 of ref. 2.

The LWR spent fuel data in the CDB can be tabulated in many ways. Table 2 shows the annual discharges from BWRs and PWRs, in terms of MTIHM (metric tons initial heavy metal). These data are also available in terms of numbers of assemblies, and by burnup. The latter are summarized in Tables 3 and 4. A graphical summation through 1981 of the burnup data in Tables 3 and 4 is given in Fig. 4. This clearly shows the trend to higher burnups with time, as well as the increasing quantities that were discharged.

Radiological characteristics important to handling and shielding include the thermal power, curies of gamma emissions, and the neutron production rate. Fig. 5 shows the thermal power for standard burnup fuel (about 30,000 MWD/MTIHM) from 5 yrs after discharge to 1000 years. During this time the major gamma, beta, and neutron sources (Sr-90, Cs-137, Co-60, Cm-244, etc.) decay away, leaving a much lower, but very longlive 1 , residue of nuclides, primarily actinides (which are the source of alpha emissions). The actinide content of spent fuel is impoitant for at least three broad reasons: neutron source strength (shielding), fissionable material content (criticality and burnup credit), and long-term alpha source strength (risk analysis). We have recently learned ${ }^{4}$ that enrichment has a major effect on the actinide contents calculated by ORIGEN2, and are therefore in process of revising these radiological properties of spent fuel. The revised calculations will make use of operational data already in the CDB data bases which relate enrichment to burnup.

Defective LWR spent fuel is of special interest because it may require special handling procedures, which have not yet been identified, nor have the appropriate waste acceptance criteria been defined. This aspect of the data base is described in Section 2.5 of ref. 2 . 


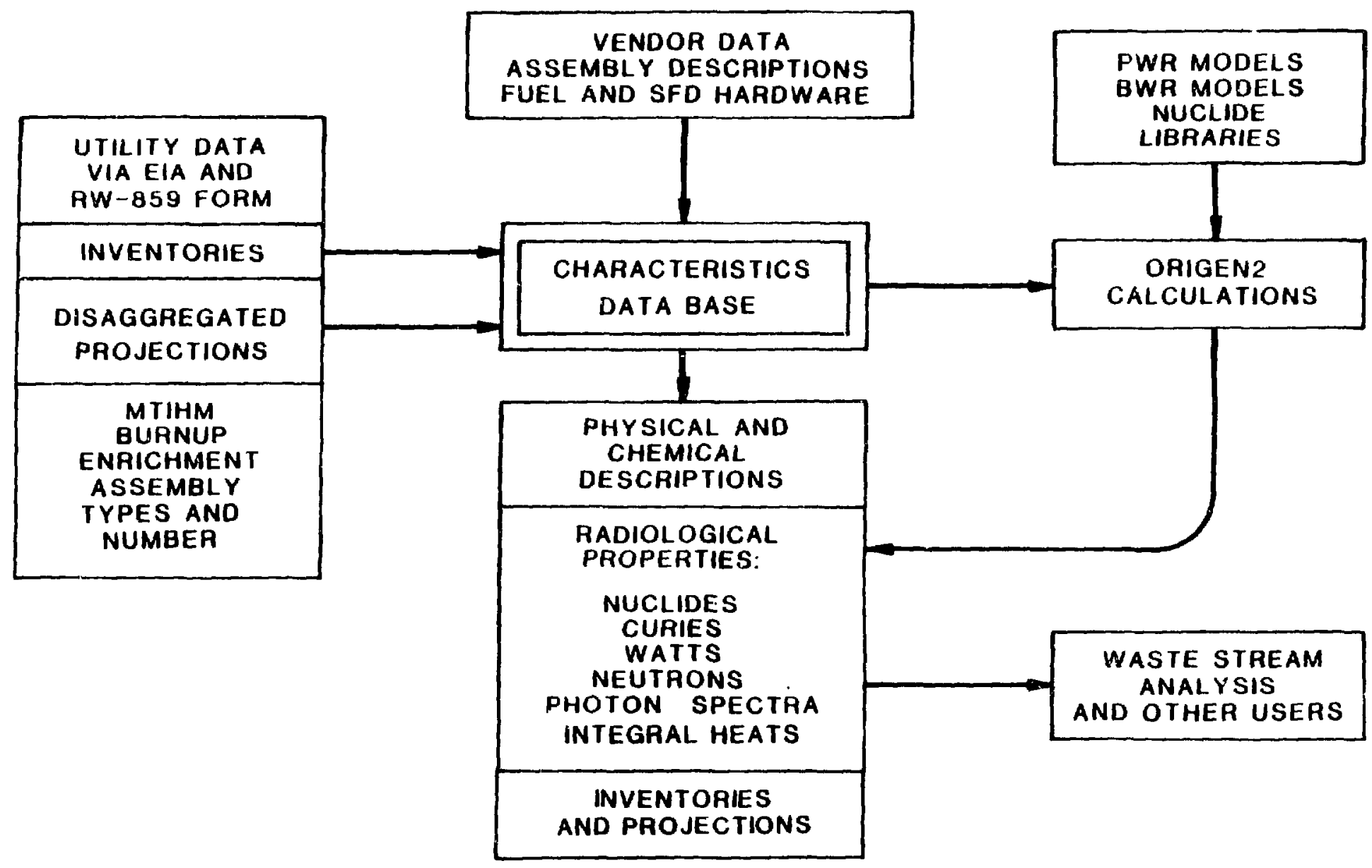

FIG. 3. CHARACTERISTICS DATA FOR LWR SPENT FUEL 
Table 2. . sumual spent fuel discharges from comnercial light-water reactors.

\begin{tabular}{|c|c|c|c|c|c|c|}
\hline \multirow{2}{*}{$\begin{array}{l}\text { End of } \\
\text { calendar } \\
\text { year }\end{array}$} & \multicolumn{2}{|c|}{ Mass, MTIHM } & \multicolumn{2}{|c|}{ Mass, HTIHM } & \multicolumn{2}{|c|}{ Mass, HTIHM } \\
\hline & Annual rate & Accumulation & Annual rate & Accumulation & Annual rate & Accumulation \\
\hline & \multicolumn{2}{|c|}{ Boiling-water reactors } & \multicolumn{2}{|c|}{ Pressurized-water reactors } & \multicolumn{2}{|c|}{ Totals } \\
\hline 1968 & 1 & 1 & 0 & 0 & 1 & 1 \\
\hline 1969 & 10 & 10 & 0 & 0 & 10 & 10 \\
\hline 1970 & 0 & 10 & 39 & 39 & 39 & 49 \\
\hline 1971 & 70 & 81 & 26 & 66 & 97 & 146 \\
\hline 1972 & 146 & 226 & 118 & 183 & 264 & 410 \\
\hline 1973 & 93 & 320 & 67 & 250 & 160 & 570 \\
\hline 1974 & 247 & 567 & 209 & 460 & 456 & 1,026 \\
\hline 1975 & 196 & 763 & 322 & 781 & 518 & 1,545 \\
\hline 1976 & 318 & 1,081 & 402 & 1,184 & 720 & 2,265 \\
\hline 1977 & 383 & 1,464 & 455 & 1,639 & 839 & 3,103 \\
\hline 1978 & 383 & 1,848 & 692 & 2,331 & 1,075 & 4,179 \\
\hline 1979 & 396 & 2,244 & 717 & 3,048 & 1,113 & 5,292 \\
\hline 1980 & 620 & 2,863 & 626 & 3,674 & 1,246 & 6,538 \\
\hline 1981 & 457 & 3,321 & 693 & 4,367 & 1,150 & 7,688 \\
\hline 1982 & 359 & 3,680 & 654 & 5,021 & 1,013 & 8,701 \\
\hline 1983 & 498 & 4,178 & 767 & 5,788 & 1,265 & 9,966 \\
\hline 1984 & 452 & 4,630 & 858 & 6,646 & 1,310 & 11,276 \\
\hline 1985 & 480 & 5,110 & 882 & 7.528 & 1,362 & 12,639 \\
\hline 1986 & 467 & 5,577 & 1,042 & 8,571 & 1,509 & 14,148 \\
\hline 1487 & 601 & 6,178 & 1,154 & 9,725 & 1,755 & 15,902 \\
\hline
\end{tabular}




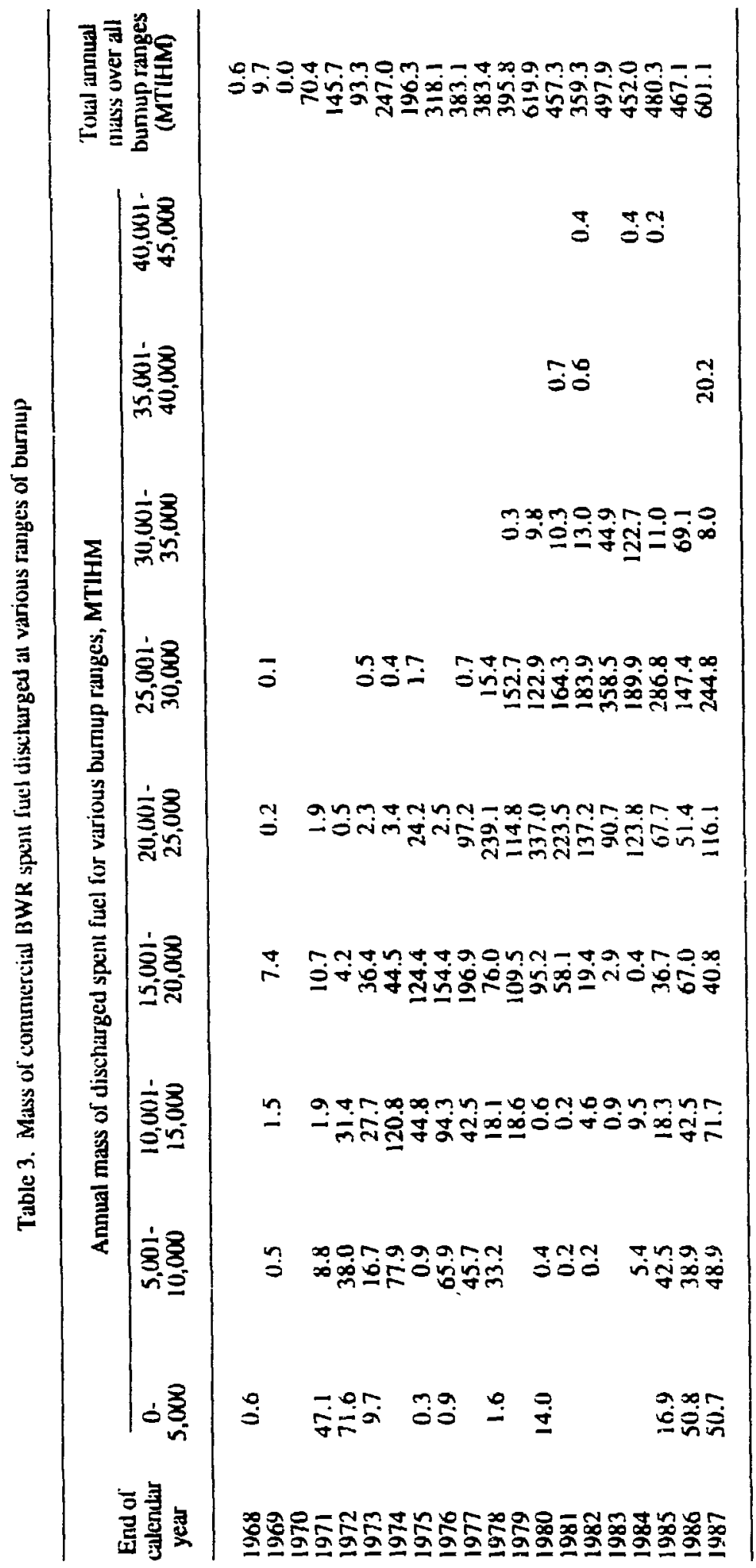




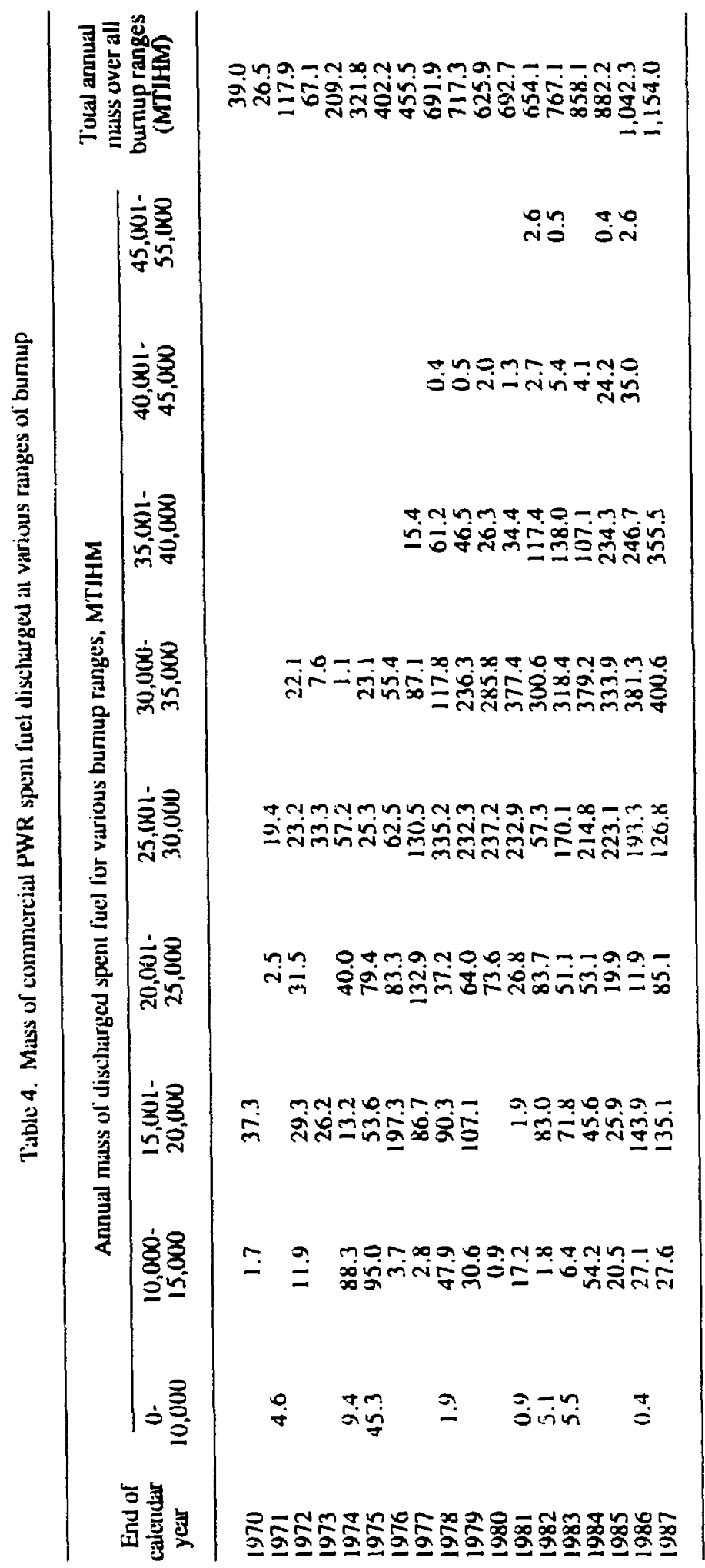


ORNL DWG 84-163

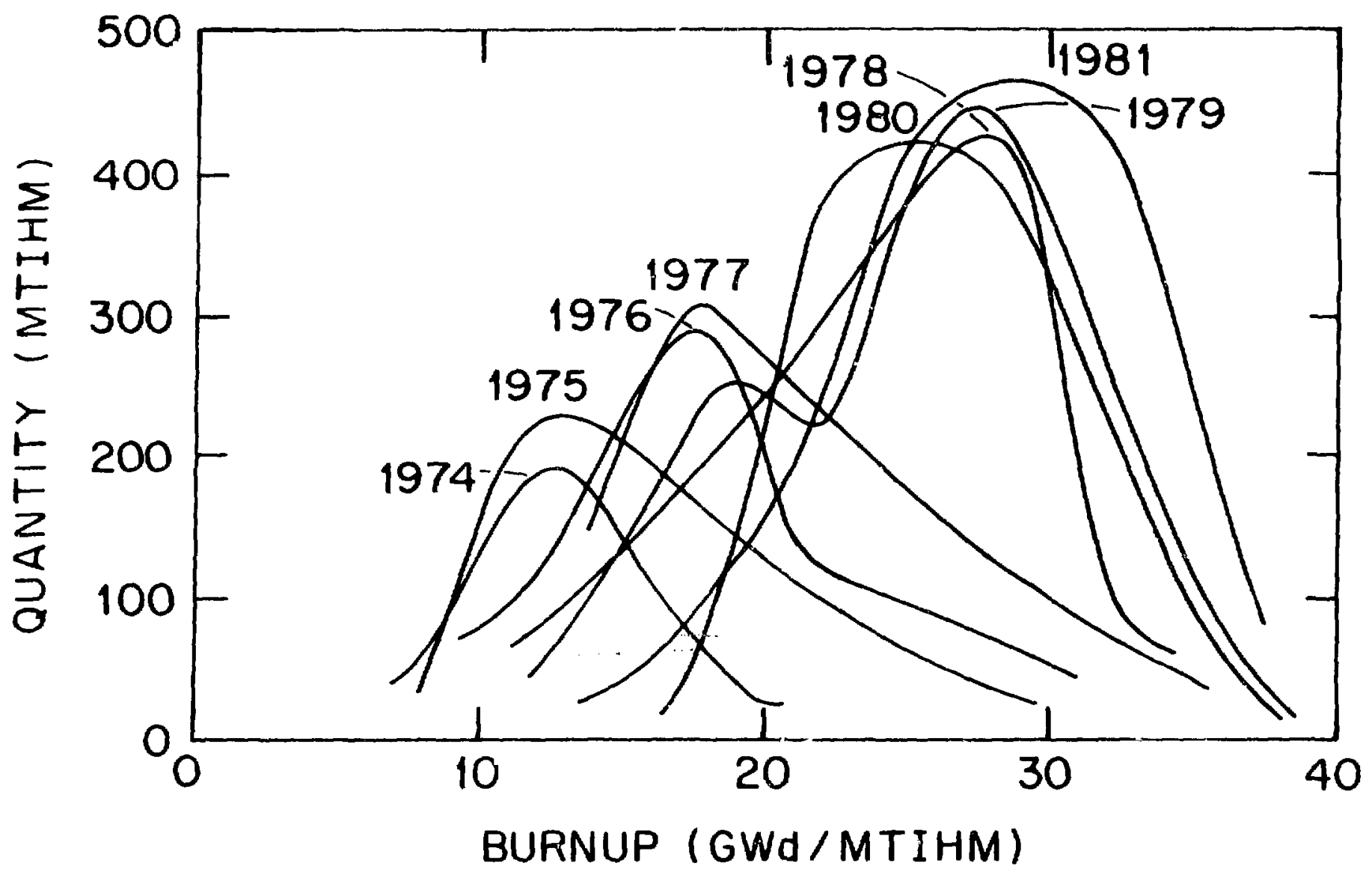

FIG. 4. DISCHARGE HISTORY OF LWR SPENT FUEL 


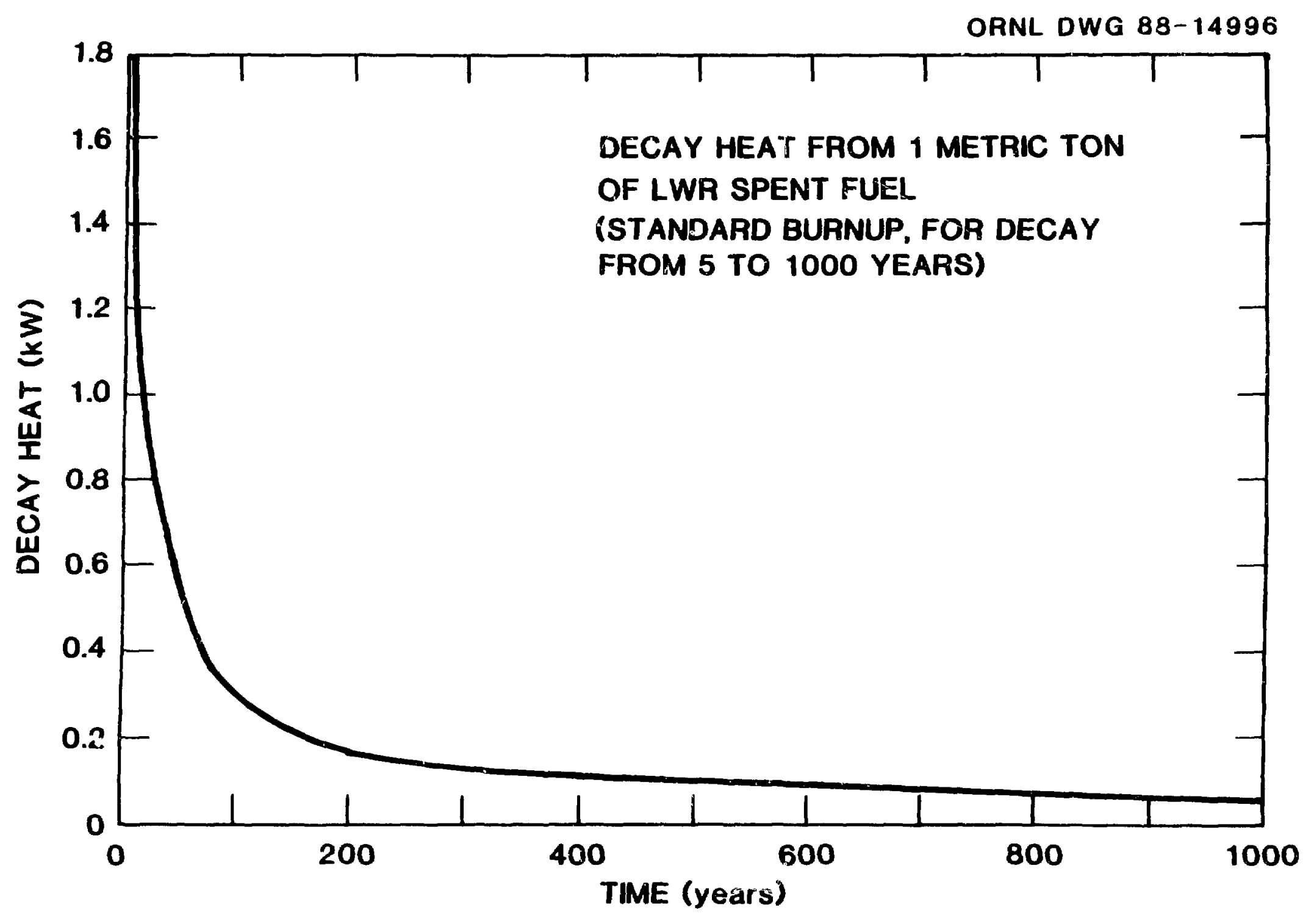

FIG. 5. DECAY HEAT OF LWR SPENT FUEL 
Table 5. Major Classes of LWR Assembly Models ${ }^{a}$

Pressurized Water Reactors:

Babcock \& Wilcox $15 \times 15$

Babcock \& Wilcox $17 \times 17$

Combustion Engineering $14 \times 14$

Combustion Engineering $16 \times 16$

Westinghouse $14 \times 14$

Westinghouse $15 \times 15$

Westinghouse $17 \times 17$

South Texas $17 \times 17$ XLR

Palisades $15 \times 15$

Saint Lucie II $16 \times 16$

San Onofre I $14 \times 14$

Yankee Rowe $15 \times 16$

Indian Point I $13 \times 14$

Fort Calhoun $14 \times 14$

Haddam Neck $15 \times 15$

Boiling Water Reactors:

General Electric BWR/2, 3

General Electric BWR/4, 5, 6

Lacrosse

Big Rock Point

Dresden I

Humboldt Bay

aThese classes are controlled by reactor core configuration. For PWRs, the array size is fixed because of control rod positions within assemblies. For BWRs, the array size is not fixed because the cruciform control blades operate in between assemblies. For both types there are a number of early, one-of-a-kind reactors, identified by reactor name. Later versions are generic. For each class there are several model types manufactured. 
Although there are 78 different assembly types listed in the data base, many of these are virtually identical, differing only in minor details or manufacturer, their basic design or configuration being controlled by reactor core design. There are 21 such "assembly classes" (Table 5), plus a number of variants that represent a very limited number of discharged assemblies. A detailed description of this classification scheme, which was developed as part of this work, has been published. ${ }^{5}$ A supplemental report on GE BWR assemblies has also been issued. 6

High-Level Waste

Immobilized HLW will derive from one commercial operation (West Valley) and three defense sites: Savannah River, Hanford, and Idaho. The first three will produce borosilicate giass by a vitrification process while Idaho, which is storing its $\mathrm{HLW}$ in the form of a calcine (rather than liquid, sludige, or salt cake), plans to produce a high-density ceramic waste form. All four sites plan to use canisters 10 -ft long by $24-i n$ in diameter. For completeness, the data base aiso includes the characteristics of the interim waste forms at the four sites, since this will be the feed material for future immobilized HLW. The data base includes detailed information, year-by-year, on the projected number of canisters and their radiological and thermal properties. A condensed summary of this type data is given in Table 6.

\section{Non-LWR Spent Fuel}

This category includes HTGR reactors, research and test reactors, and miscellaneous fuels from various reactors now stored at nine locations. Table 7 gives a summary of these fuels. Note that for the HTGRs the quantity is the number of fuel elements, for the FFTF it is the number of assemblies, while the others are in metric tons of heavy metal (MTHM). The Idaho total does not include the Shippingport LWR Breeder core, which contains $770 \mathrm{~kg}$ of $\mathrm{U}$, mostly U-233, and 47.21 MT of thorium. In addition, the HTGR fuel is also at the Idaho facility. The thermal outputs of these spent fuels are generally quite low. However, the diversity of chemical compositions and physical 
Table 6. Characteristics of immobilized HLW

\begin{tabular}{|c|c|c|c|c|}
\hline & West Valley & $\begin{array}{l}\text { Savannah } \\
\text { River }\end{array}$ & Hanford & Idaho \\
\hline Weight of canister $(\mathrm{kg})$ & 252 & 500 & 500 & 500 \\
\hline Weight of contents $(\mathrm{kg})$ & 1895 & 1682 & 1650 & 1825 \\
\hline Total weight $(\mathrm{kg})$ & 2147 & 2182 & 2150 & 2325 \\
\hline Kilocuries (per canister)a & 125 & 234 & 416 & 143 \\
\hline Watts (per canister)a & 380 & 700 & 1150 & 340 \\
\hline Projected startup (year) & 1992 & 1992 & 1999 & 2011 \\
\hline \multicolumn{5}{|l|}{$\begin{array}{l}\text { Projected No. of canisters } \\
\text { (cumulative) in: }\end{array}$} \\
\hline $\begin{array}{l}1992 \\
1995 \\
2000 \\
2005 \\
2010 \\
2015 \\
2020\end{array}$ & $\begin{array}{l}275 \\
275 \\
275 \\
275 \\
275 \\
275 \\
275\end{array}$ & $\begin{array}{r}922 \\
2152 \\
4202 \\
5302 \\
5890 \\
6350 \\
6810\end{array}$ & $\begin{array}{r}0 \\
0 \\
653 \\
1305 \\
1860 \\
1860 \\
1860\end{array}$ & $\begin{array}{r}0 \\
0 \\
0 \\
0 \\
0 \\
3800 \\
8800\end{array}$ \\
\hline
\end{tabular}

aThese are maximum values at ime of loading. For West Valley, with a fixed input, the average is $10-20 \%$ lower. For the defense sites, wich future input undefined, the averages may be much lower tha:" the maximum values listed. 
HTGRs:

Peach Bottom I

Core $\bar{I}$

Core II

Fort St. Vrain

804 elements

804 elements

725 elements

Research/Test Reactors:

MTR Plate Fuel

TRIGA

$\mathrm{UO}_{2}$-in-Polyethylene

PULSTAR

FFTF

170 assemblies

Miscellaneous Fuels:

Argonne

Babcock \& Wilcox

Battelle-Columbus

Battelle-PNL

Hanford

Idaho

Los Alamos

Oak Ridge

Savannah River

0.31 MTHM

0.05 MTHM

$1.50 \mathrm{MTHM}$

2.25 MTHM

0.07 MTHM

38.06 MTHM

$0.13 \mathrm{MTHM}$

$1.28 \mathrm{MTHM}$

19.02 MTHM

aData as of December 31,1987. 
configurations, coupled with the high enrichments of many of them, may impose some challenging packaging and disposal considerations. An initial study has provided some broad guidelines in this regard. ${ }^{7}$ For example, regarding possible criticality, both generic and limited specific calculations indicate that a relatively small volume increment (10 to 20\%) for the deliberate addition of neutron poisons would reduce k(effective) to less than 0.85 for even the most sensitive configurations and environments.

\section{Miscellaneous Wastes}

This category includes wastes that are neither spent fuel nor HLW, but which may not qualify for commercial low-level disposal, nor as defense TRU waste. In the absence of intermediate depth disposal or greater-confinement disposal, these materials may be future candidates for consideration for repository disposal. Thus, they are included in the Characteristics Data Base, in order to provide technical data on these materials. Marly of them are in the category of Greater-than-Class-C Low-Level Waste, and are not eligible for shallow-land burial without an exemption from the Nuclear Regulatory Commission. Wastes presently included in this section are OCRWM-generated wastes, commercial TRU waste, reactor decommissioning waste, radioisotope capsules, and certain LWR operational wastes.

\section{Future Work}

A inajor revision and update of the entire report and PC data bases is planned for 1990. This revision will include two additional PC data bases, on LWR Fuel Pin Characteristics and on LWR Assembly Serial Numbers. Descriptive data on recentlyintroduced LWR assembly models will be added and all inventories and projections will be updated. Improved cescriptions of HLW will be incorporated. Radiological calculations for LWR fuel and hardware will be improved by using improved cross section and enrichment data for the spent fuel and newly developed activation parameters for the activated hardware. 
1. J. W. Roddy, et al., "Physical and Decay Characteristics of Commercial LWR Spent Fuel," ORNL/TM-9591, January 1986.

2. "Characteristics of Spent Fuel, High-Level Waste, and Other Radioactive Wastes Which May Require Long-Term Isolation," DOE/RW-0184, Vols. 1-6

(December 1987) and Vols. 7-8 (June 1988):

Volume 1. Jummary, LWR Spent Fuel, and Immobilized High-Level Waste.

Volume 2. App. 1A ORIGEN2 Overview

App. 1B ORIGEN2 Library Data

App. IC ORIGEN2 Interpolation Functions

Volume 3 App. 2A Physical Descriptions of LWR Fuel Assembly

Volume 4. App. 2B User's Guide to the LWR Assemblies Data Base

App. 2C User's Guide to the LWR Radiological Data Base

App. 2D User's Guide to the LWR Quantities Data Base

Volume 5. App. 2E Physical Descriptions of LWR NFA Hardware

App. 2F User's Guide to the High-Level Waste PC Data Base

Volume 6. App. 3A ORIGEN2 Decay Tables for Immobilized High-

App. 3B Interim High-Level Waste Forms

App. 3C User's Guide to the High-Level Waste PC data Base

Volume 7. Non-LWR Spent Fuels and Miscellaneous Wastes

Volume 8. App. 4A Nuclear Reactors at Educational Institutions in the United States

App. 4B Data Sheets for Nuclear Reactors at Educational Institutions

App. 4C Supplemental Data for St. Vrain Spent Fuel

App. 4D Supplemental Data for Peach Bottom 1 Spent Fuel

3. A. G. Croff, "ORIGEN2 - A Revised and Updated Version of the Oak Ridge Isotope Generation and Depletion Code," ORNL-5621, July 1980, and "A User's Manual for the ORIGEN2 Computer Code," ORNL/TM-7175, July 1980.

4. Karl J. Notz anc' Timothy D. Welch, "ORIGEN2 Sensitivity to Enrichment and Other Factors," ORNL/TM - to be published.

5. R. S. Moore, D. A. Williamson, and K. J. Notz, "A Classification Scheme for LWR Fuel Assemblies," ORNL/TM-10901, November 1988. 
6. R. S. Moore, "Physical Characteristics of GE Fuel Assemblies," ORNL/TM-10902, April 1989.

7. Royes Salmon, Karl Notz, and Calvin Hopper, "Non-I_WR and Special LWR Spent Fuels: Characteristics and Criticality Aspects of Prckaging and Disposal," ORNL/TM-11016, to be published. 